\title{
A SWOT analysis of physical infrastructure in government-owned university libraries in Ogun State, Nigeria
}

\author{
Esther Abosede Awojobi ${ }^{1}$, Clara Chinyere Okoro² \\ and Yemisi Tomilola Babalola ${ }^{3}$ \\ awojobi.esther@oouagoiwoye.edu.ng ORCID: 0000-0001-6569-3897 \\ okoroc@babcock.edu.ng ORCID: 0000-0002-4570-8972 \\ babalolay@babcock.edu.ng ORCID: 0000-0003-0506-6976
}

\begin{abstract}
Received: 17 May 2020
Accepted: 15 October 2020

The adequacy of the physical infrastructure of three government-owned university libraries in Ogun State, Nigeria, were evaluated using a strengths, weaknesses, opportunities and threats (SWOT) analysis. Results showed that the libraries have strengths in terms of their geographical locations, accessibility by road, ventilation, space for individual activities, and shelving. Infrastructural weaknesses are in the areas of service to the physically challenged, noise and seating capacity. Poor maintenance and funding are threats to the libraries' infrastructure. It is recommended that accrediting bodies consider reviewing standard requirements for seating capacity, while serious attention should be paid to the needs of the physically challenged in the construction of library buildings.
\end{abstract}

Keywords: SWOT, university library, infrastructure, evaluation, standards

\section{Introduction}

Accreditation exercises are one of the ways in which the quality of university infrastructure is judged. University libraries, like other types of academic libraries, are faced with the predicament of decaying infrastructure. To address this problem, it is imperative to carry out a situation analysis so that appropriate strategic plans can be put in place to resolve it. A strengths, weaknesses, opportunities and threats (SWOT) analysis is an evaluative tool that can be used to this effect. "There is a proliferation of strategic planning tools to enable managers to formulate competitive strategies in line with the requirements of their business environments" (Panagiotou 2003: 8), but SWOT analysis is used more than any other management technique in the process of decision making (Panagiotou 2003: 8). SWOT analysis is an evaluative technique that is gaining wide acceptability even in libraries. Literature abounds in relation to trends in academic libraries, as well as challenges, issues and opportunities in the library. There is, however, a dearth of information on SWOT analyses done for university libraries in developing countries, Nigeria included. As libraries do not exist in isolation, it is important to know how well they interact with their environment and to gain insights into changes as well as competition in and around them. Ghosh (2006) reported that the analysis allows for "the identification of needs, potential problems and issues", and plays a role in allowing the library to respond to emerging trends and challenges in the environment. This research embarked on a SWOT analysis of the physical infrastructure of university libraries in a developing country using government-owned universities in Ogun State, Nigeria, as case studies. Ogun State is a leader in university education in Nigeria. Like most other states in the country, it has a federal university. Unlike most of the other states in the country, it also has two state government-owned universities.

\section{Physical facilities and infrastructure in university libraries}

"School facilities constitute the major components of both direct and indirect elements in the learning environment" (Asiabaka 2008: 10); the quality of the university library facility is therefore an important component of the reputation of the university. It is imperative that universities provide the necessary infrastructure to enable the library to contribute to the realisation of the university's goals and objectives (Ogbuiyi and Okpe 2013: 34). Library infrastructure includes power generating sets, electrical installations, furniture, fittings, information materials, a multipurpose library building, and information communication technology (ICT) facilities (Ogbuagu, Ubi and Effiom 2014 cited in Omeluzor, 2018: 2). Library

1. Esther Abosede Awojobi is a postgraduate student at Babcock University. She is Principal Librarian at Olabisi Onabanjo University, Ago Iwoye, Ogun State, Nigeria

2. Clara Chinyere Okoro is University Librarian at Babcock University, Ilishan Remo, Ogun State, Nigeria

3. Yemisi Tomilola Babalola is Head of Department of the Department of Information Resources Management at Babcock University, Ilishan Remo, Ogun State, Nigeria 
infrastructure can also include chairs, bookshelves and tables, toilet facilities, ICT facilities, adequate library space, restaurant/coffee rooms, lighting and ventilation, parking, catalogue systems, fans and air conditioners (Iwhiwhu and Okorodudu 2012: 4). According to Omeluzor, Nwosu and Molokwu (2018: 1), the activities and functions of the university library hinge on the development, availability and functionality of its infrastructure. Infrastructure provides the foundation for self-sustaining growth. The environment in which library materials are housed and the way in which they are handled could pose a threat to their longevity; library materials are always aging and prudent information storage handling can prolong their usefulness. More so, natural disasters such as fires, lightning and floods can destroy library materials. Alegbeleye (1996) cited by Ogunsola and Ikegune (2016: 12) advocated for a preventive conservation and preservation approach in African countries, which should focus on improving the environment, controlling light, temperature, humidity and pollution. The physical appearance of every facility in a library has the potential to attract or put off potential users (Arthur, Brafi and Kuranchie 2013: 124). It has been established that physical infrastructure affects the use of the library (Oyedum 2011: 13). A study of Okoro, Omeluzor and Bamidele (2014) revealed that the inadequacy of facilities could also harm staff. It is important for service organisations like academic libraries to structure their physical environment effectively in a way that will attract and as well as promote effectiveness in service delivery and encourage a quality academic library collection.

To appeal to more users, libraries should be attractive in terms of aesthetics and general ambience (Kisiedu 2010 cited in Arthur, Brafi and Kuranchie 2013: 124). Shill and Tonner (2013: 5) considered the following to be essential for an academic library building that intends to increase patronage: "quality and variety of seating and work surfaces, number of public access workstations, number of data ports, percentage of seats with network access (wired or wireless), logical location of service points, quality of telecommunication infrastructure, number of group study rooms, presence of a snack bar". They also said that: "hours of operation per week, food/drink policy, quality of natural and artificial lighting, quality of heating, ventilation and air conditioning systems, and interior colour selection are required to promote patronage" (Shill and Tonner 2013: 5). A favourable work environment correlates with the high productivity of personnel in any organisation. 'Work environment' can be considered to be "the physical, social, psychological and technological conditions that are found in the work places that impart the job performance of librarians" (Amusa, lyoro and Olabisi 2013: 458). Oyedum (2011: 1) asserted that environmental factors such as good ventilation, noise-free reading areas, and physical facilities such as furniture and lighting are necessary for adequate use of university libraries.

\section{SWOT analysis of university library infrastructure}

Kumar (2012) evaluated four university libraries in Kerala, India (Kerala University Library, Mahatma Gandhi University Library, Cochin University of Science and Technology Library, and CH Mohammed Koya Library of University of Calicut) using a SWOT analysis. He identified the following as library infrastructural strengths: the size and layout of the library building and its accessibility to students, teachers and the general public. All four university libraries were found to have functional, modular buildings. However, among these libraries, only one (Kerala University Library) had library location as a strength. All university libraries surveyed by Kumar (2012) were multi-storey buildings with no elevators - a weakness in terms of accessibility for the physically challenged. In Hazidah and Edzan's (2012) study, in addition to a seating capacity of up to 2,000, the University of Malaya was in an easily accessible location and had some other distinctive areas of strength such as the presence of cafes and a prayer room. The university, however, had the weakness of limited parking areas (Hazidah and Edzan 2012: 3). According to Ugah (2007: 5), the Michael Okpara University of Agriculture Library had among other weaknesses, a seating capacity of a wholly inadequate 148 to service the entire university community. De Bruijn (2000: 5) reported that the University of British Columbia Library also had inadequate, substandard and poorly maintained spaces and facilities. The SWOT analysis of library infrastructures reviewed here are excerpts from the general SWOT analysis of university libraries. There is a dearth of detailed studies applying SWOT analyses to library infrastructure.

\section{Methodology}

The objective of this paper is to report findings of a SWOT analysis of the physical infrastructure of government-owned university libraries in Ogun State, Nigeria. The research question is: What are the strengths, weaknesses, opportunities and threats related to university libraries in Ogun State in terms of physical infrastructure? A case study approach was used for this study as it required an in-depth study of the university libraries' internal and external environment. The selected universities were two state government-owned universities - Olabisi Onabanjo University (OOU) and Tai Solarin University of Education (TASUED) - and one federal government-owned university, the Federal University of Agriculture Abeokuta (FUNAAB). The universities were established in 1982 (OOU); 2005 (TASUED) and 1988 (FUNAAB). Each of these universities has passed through a series of accreditations by the main accrediting body for university education in Nigeria, the National Universities Commission (NUC). The study population was professional librarians in the three universities purposively selected for this study. The total size of the population was fifty with a breakdown as follows: OOU (14); TASUED (10); FUNAAB (26). 
Two instruments of data collection were used. The first instrument was the University Libraries SWOT Analysis Questionnaire for Librarians. Section A of the questionnaire elicited demographic information of interest from the respondents. Such information included the name of their institution, gender, educational qualification, subject background, designation, and length of service. Section B elicited information on physical infrastructure and facilities in the libraries. The section contained information on the location and accessibility of the libraries, readers' seating/space requirements, shelving space and light levels. Respondents were expected to indicate their level of agreement on statements made according to four rating levels: (1) Strongly Agree (SA), (2) Agree (A), (3) Disagree (D) and (4) Strongly Disagree (SD). Respondents were also asked to identify the strengths, weaknesses, opportunities and threats that they associated with their libraries. The second instrument was the University Libraries SWOT Observation Checklist. It contained eleven items of observation on library physical infrastructure and facilities. The observations were recorded according to the following scale of: Meets Expectation (ME), Needs Improvement (NI) and Not Observed (NO). The research instruments were validated for content and face validity by experts in the field of Library and Information Science. They were then pretested to ascertain their reliability. The questionnaires were pretested on academic librarians of the University of Ibadan and the data were subjected to reliability analysis using Cronbach's alpha. Results showed the value for physical infrastructure and building as 0.81 .

The researchers, with the assistance of four trained research assistants, administered and retrieved the questionnaires. The assistants were trained to minimise errors in the field. They offered assistance to the respondents in filling out the questionnaires. To collect the data, scheduled visits were made to the libraries to administer the questionnaires in person. Data collected during the process was organised, coded and analysed. Respondents' information was treated with the utmost confidentiality and used for research purposes only. The observation aspect of the research was completed by one of the researchers. Data obtained are presented as descriptive statistics. The descriptive statistics include frequency counts, mean, standard deviation and percentages. Statistical analysis was carried out using the Statistical Package for Social Sciences (SPSS).

\section{Results}

The result of the assessment of physical infrastructure and facilities at FUNAAB is presented in Table 1. There is an overall positive assessment of physical infrastructure and facilities with a mean of 3.12. All assessments for location and accessibility (S/N 1-10) had mean ratings that were above 3.00, except friendliness to the physically challenged (S/N 8). Accommodating the physically challenged is an accessibility weakness; the remaining nine are strengths of location and accessibility. Under reader seating/space requirement, Table 1 shows that the library has enough and conducive space for individual activities; each space is between 2.5 and 4 square meters and this is a strength. However, the library cannot seat $20 \%$ of its user population and the electronic library cannot support $5 \%$ of its users. In terms of shelving, each stacked area is at least 10.75 square meters which is a strength as it the light level - as a well-illuminated library is a strength. Table 2 shows the result of the SWOT analysis of physical infrastructure and facilities as perceived by FUNAAB librarians. The indices (the geographical location of the library, parking area, space for individual activities in the library, seating capacity, shelf space, maintenance culture and technology) are all regarded as strengths.

The result of the assessment of physical infrastructure and facilities by OOU librarians is presented in Table 3. Physical infrastructure and facilities were positively rated with a mean of 2.99. The areas with mean scores less than 3.00 and tending towards weaknesses are: the library's friendliness to the physically challenged; noise-free floors; the library being able to seat at least $20 \%$ of its user population; and the electronic library being able to accommodate at least $5 \%$ of the user population. Table 4 presents a SWOT rating of infrastructure and facilities at OOU. Except for maintenance culture, all other measurements were regarded as strengths of infrastructure and facilities.

The assessment of physical infrastructure and facilities at TASUED is presented in Table 5 . The overall mean value for the assessment is 2.69 which approximates to low strength. Location and accessibility indicators with mean values greater than 3.00, and therefore high strengths, include: the location of the library allowing for ease of access; the appeal of its location; and the library's accessibility by road. Low strengths include: a location devoid of noise and distractions; a library environment of sufficient aesthetic value; a library space which inspires study and learning; and a well-ventilated and suitably heated/cooled facility. Adequate amenities with water, accommodating to the physically challenged, and noise-free areas are part of the infrastructural and facilities weaknesses at TASUED Library. Indices of reader seating/space requirement that constitute low strength and therefore weakness of infrastructure and facilities include: enough and conducive space for individual activities; each study space being between 2.5 and 4 square meters; the library's ability to seat $20 \%$ of its user population; and the electronic library's ability to accommodate at least $5 \%$ of the user population. Shelving space and light levels are low strengths. 
Table 1: Assessment of physical infrastructure and facilities by FUNAAB librarians

\begin{tabular}{|c|c|c|c|c|c|c|c|}
\hline $\mathbf{S} / \mathbf{N}$ & Statement & $\begin{array}{l}\text { SA (4) } \\
\text { Freq (\%) }\end{array}$ & $\begin{array}{c}\text { A (3) } \\
\text { Freq (\%) }\end{array}$ & $\begin{array}{l}D(2) \\
\text { Freq (\%) }\end{array}$ & $\begin{array}{l}\text { SD (1) } \\
\text { Freq \%) }\end{array}$ & Mean & SD \\
\hline & Location and accessibility & & & & & & \\
\hline 1 & The library is centrally located for ease of access & $14(60.9 \%)$ & $9(39.9 \%)$ & - & - & 3.61 & 0.50 \\
\hline 2 & The library is in a comfortable and inviting location & $11(47.8 \%)$ & $12(52.2 \%)$ & - & - & 3.48 & 0.51 \\
\hline 3 & The library is accessible through good road network & $8(34.8 \%)$ & $13(56.5 \%)$ & $2(8.7 \%)$ & - & 3.26 & 0.62 \\
\hline 4 & $\begin{array}{l}\text { Location is devoid of noise and other distractive } \\
\text { activities }\end{array}$ & $9(39.1 \%)$ & $12(52.2 \%)$ & $2(8.7 \%)$ & - & 3.30 & 0.63 \\
\hline 5 & Library environment offers sufficient aesthetic value & $7(30.4 \%)$ & $15(65.2 \%)$ & $1(4.3 \%)$ & - & 3.26 & 0.54 \\
\hline 6 & $\begin{array}{l}\text { The library is well ventilated with suitable cooling } \\
\text { systems in place }\end{array}$ & $7(30.4 \%)$ & $15(65.2 \%)$ & $1(4.3 \%)$ & - & 3.26 & 0.54 \\
\hline 7 & There are adequate toilet facilities with water & $12(52.2 \%)$ & $9(39.1 \%)$ & $2(8.7 \%)$ & - & 3.40 & 0.66 \\
\hline 8 & The library is friendly to physically challenged & $4(17.4 \%)$ & $5(21.1 \%)$ & $4(17.4 \%)$ & $10(43.5 \%)$ & 2.13 & 1.18 \\
\hline 9 & The library space inspires study and learning & $9(39.1 \%)$ & $14(60.9 \%)$ & - & - & 3.39 & 0.50 \\
\hline \multirow[t]{2}{*}{10} & The floor is noise free & $8(34.8 \%)$ & $12(52.2 \%)$ & $3(13 \%)$ & - & 3.22 & 0.67 \\
\hline & Reader seating/space Requirement & & & & & & \\
\hline 11 & $\begin{array}{l}\text { The library has enough and conducive space for } \\
\text { individual activities }\end{array}$ & $10(43.5 \%)$ & $13(56.5 \%)$ & - & - & 3.43 & 0.51 \\
\hline 12 & The library can seat at least $20 \%$ of user population & - & $12(52.2 \%)$ & $6(26.1 \%)$ & $5(21.7 \%)$ & $2.3 f 0$ & 0.82 \\
\hline 13 & Each study space is between 2.5 and 4 square meters & $6(26.1 \%)$ & $15(65.2 \%)$ & $2(8.7 \%)$ & - & 3.17 & 0.58 \\
\hline \multirow[t]{2}{*}{14} & $\begin{array}{l}\text { The electronic library can accommodate at least } 5 \% \text { of } \\
\text { the user population }\end{array}$ & - & $10(43.5 \%)$ & $6(26.1 \%)$ & 7 (30.4\%). & 2.13 & 0.87 \\
\hline & Shelving space & & & & & & \\
\hline \multirow[t]{2}{*}{15} & Each stack area is at least 10.75 square meters & $6(26.1 \%)$ & $14(60.9 \%)$ & $3(13 \%)$ & - & 3.13 & 0.63 \\
\hline & Light level & & & & & & \\
\hline \multirow[t]{2}{*}{16} & The library is well illuminated & 9 (39.1\%) & 14 (60.9\%) & - & - & 3.39 & 0.50 \\
\hline & Overall Mean $=3.12$ & & & & & & \\
\hline
\end{tabular}

Key: Strongly Agreed = SA, Agreed = A, Disagreed = D, Strongly Disagree $=$ SD, Mean $=\bar{x}, \pm S D=$ Standard deviation

Table 2: Perceived SWOT by FUNAAB librarians of physical infrastructure and facilities

\begin{tabular}{|c|c|c|c|c|c|c|c|}
\hline $\mathbf{S} / \mathbf{N}$ & Statement & $\begin{array}{c}S(4) \\
\text { Freq (\%) }\end{array}$ & $\begin{array}{c}\text { W (2) } \\
\text { Freq (\%) }\end{array}$ & $\begin{array}{c}O(3) \\
\text { Freq (\%) }\end{array}$ & $\begin{array}{c}\mathrm{T}(1) \\
\text { Freq (\%) }\end{array}$ & Mean & SD \\
\hline 1. & Geographical location of the library & $22(95.7 \%)$ & $1(4.3 \%)$ & - & - & 3.91 & 0.42 \\
\hline 2. & Parking area & $18(78.3 \%)$ & $5(21.7)$ & - & - & 3.57 & 0.84 \\
\hline 3. & Space for individual activities in the library & $19(82.6 \%)$ & $3(13 \%)$ & $1(4.3 \%)$ & - & 3.70 & 0.70 \\
\hline 4. & Seating capacity & $16(69.6 \%)$ & $6(26.1 \%)$ & - & $1(4.3 \%)$ & 3.35 & 1.03 \\
\hline 5. & Shelf space & $19(82.6 \%)$ & $4(17.4 \%)$ & - & - & 3.65 & 0.78 \\
\hline 6. & Maintenance culture & $7(30.4 \%)$ & $14(60.9 \%)$ & 2 (8.7\%) & & 2.70 & 0.92 \\
\hline 7. & Technology & $13(56.3 \%)$ & $4(17.4 \%)$ & $6(26.1 \%)$ & - & 3.39 & 0.78 \\
\hline
\end{tabular}

Key: Strengths (S), Weaknesses (W), Opportunities (O) or Threats (T) to infrastructure and facilities

Table 6 shows the TASUED Library SWOT rating for some features of infrastructure and facilities. The geographical location of the library was rated as a source of strength by all respondents. Seating capacity was also rated as a source of strength, by $62.5 \%$ of respondents. The parking area, space for individual work and shelf space were rated by $75 \%, 62.5 \%$, and $75 \%$ of respondents respectively as infrastructural weaknesses. Maintenance culture was rated by $100 \%$ of respondents as a threat, while $81.5 \%$ of respondents rated technology as an opportunity. Table 7 presents the result of observations on infrastructure and facilities in the libraries surveyed. FUNAAB Library meets expectations in terms of location, accessibility, its lack of distractions, its noise-free floor, its spacious stacks, and its lighting. Improvement is needed in terms of aesthetics, space for individual activities, furniture, and ventilation (especially during power outages). At OOU, the library meets expectations in terms of ventilation irrespective of power source, toilet facilities, stack space, and lighting. 
Improvement is needed in the areas of distractions around the library as well as aesthetics and conducive space for individual activities. Noise of the floor also requires attention. TASUED Library meets expectations in terms of location, road accessibility, aesthetics, stack space, and lighting. However, improvement is needed in the areas of curbing distractions, space for individual activities, adequate toilet facilities, and flooring.

Table 3: Assessment of physical infrastructure and facilities by OOU librarians

\begin{tabular}{|c|c|c|c|c|c|c|c|}
\hline $\mathbf{S} / \mathbf{N}$ & Statement & $\begin{array}{l}\text { SA (4) } \\
\text { Freq (\%) }\end{array}$ & $\begin{array}{c}A(3) \\
\text { Freq (\%) }\end{array}$ & $\begin{array}{c}\text { D (2) } \\
\text { Freq (\%) }\end{array}$ & $\begin{array}{c}\text { SD (1) } \\
\text { Freq (\%) }\end{array}$ & Mean & SD \\
\hline & Location and accessibility & & & & & & \\
\hline 1 & The library is centrally located for ease of access & $9(69.2 \%)$ & $3(23.1 \%)$ & $1(7.7 \%)$ & - & 3.62 & 0.65 \\
\hline 2 & The library is in a comfortable and inviting location & $8(61.5 \%)$ & $5(38.5 \%)$ & - & - & 3.62 & 0.51 \\
\hline 3 & The library is accessible through good road network & $8(61.5 \%)$ & $5(38.5 \%)$ & - & - & 3.62 & 0.51 \\
\hline 4 & Location is devoid of noise and other distractive activities & $6(69.2 \%)$ & $5(38.5 \%)$ & $2(15.4 \%)$ & - & 3.31 & 0.75 \\
\hline 5 & Library environment offers sufficient aesthetic value & $4(30.8 \%)$ & $6(46.2 \%)$ & $3(23.1 \%)$ & - & 3.08 & 0.76 \\
\hline 6 & $\begin{array}{l}\text { The library is well ventilated with suitable cooling systems } \\
\text { in place }\end{array}$ & $5(38.5 \%)$ & $7(53.8 \%)$ & - & $1(7.7 \%)$ & 3.23 & 0.83 \\
\hline 7 & There are adequate toilet facilities with water & $4(30.8 \%)$ & $8(61.5 \%)$ & $1(7.7 \%)$ & - & 3.23 & 0.83 \\
\hline 8 & The library is friendly to physically challenged & $3(23.1 \%)$ & $1(7.7 \%)$ & $6(46.2 \%)$ & $3(23.1 \%)$ & 2.31 & 1.11 \\
\hline 9 & The library space inspires study and learning & $5(38.5 \%)$ & $7(53.8 \%)$ & - & $1(7.7 \%)$ & 3.31 & 0.63 \\
\hline \multirow[t]{2}{*}{10} & The floor is noise free & - & $8(61.5 \%)$ & $1(7.7 \%)$ & $4(30.8 \%)$ & 2.31 & 0.95 \\
\hline & Reader seating/space Requirement & & & & & & \\
\hline 11 & $\begin{array}{l}\text { The library has enough and conducive space for } \\
\text { individual activities }\end{array}$ & $3(23.1 \%)$ & $8(61.5 \%)$ & $2(15.4 \%)$ & - & 3.08 & 0.64 \\
\hline 12 & The library can seat at least $20 \%$ of population & - & $3(23.1 \%)$ & $7(53.8 \%)$ & $3(23.1 \%)$ & 2.00 & 0.71 \\
\hline 13 & Each study space is between 2.5 and 4 square meters & $1(7.7 \%)$ & $5(69.2 \%)$ & $3(23.1 \%)$ & - & 2.85 & 0.55 \\
\hline \multirow[t]{2}{*}{14} & $\begin{array}{l}\text { The electronic library can accommodate at least } 5 \% \text { of } \\
\text { the user population }\end{array}$ & - & $4(30.8 \%)$ & $8(61.5 \%)$ & $1(7.7 \%)$ & 2.23 & 0.60 \\
\hline & Shelving space & & & & & & \\
\hline \multirow[t]{2}{*}{15} & Each stack area is at least 10.75 square meters & $1(7.7 \%)$ & $8(61.5 \%)$ & $4(30.8 \%)$ & - & 2.77 & 0.60 \\
\hline & Light level & & & & & & \\
\hline 16 & The library is well illuminated & $4(30.8 \%)$ & $9(69.2 \%)$ & - & - & 3.31 & 0.48 \\
\hline
\end{tabular}

Key: Strongly Agreed = SA, Agreed = A, Disagreed = D, Strongly Disagree $=$ SD, Mean $=\bar{x}, \pm S D=$ Standard deviation

Table 4: Perceived SWOT by OOU Librarians of physical infrastructure and facilities

\begin{tabular}{|c|c|c|c|c|c|c|c|}
\hline $\mathbf{S} / \mathbf{N}$ & Statement & $\begin{array}{c}\mathbf{S}(4) \\
\text { Freq (\%) }\end{array}$ & $\begin{array}{c}\text { W (2) } \\
\text { Freq (\%) }\end{array}$ & $\begin{array}{c}O(3) \\
\text { Freq (\%) }\end{array}$ & $\begin{array}{c}\mathrm{T}(1) \\
\text { Freq (\%) }\end{array}$ & Mean & SD \\
\hline 1. & Geographical Location of the library & $7(53.8 \%)$ & $5(38.5 \%)$ & $1(7.7 \%)$ & - & 3.15 & 0.99 \\
\hline 2. & Parking area & $7(53.8 \%)$ & $4(30.5 \%)$ & $1(7.7 \%)$ & $1(7.7 \%)$ & 3.08 & 1.12 \\
\hline 3. & Space for individual activities in the library & $5(38.5 \%)$ & $3(23.1 \%)$ & $4(30.8 \%)$ & $1(7.7 \%)$ & 3.00 & 1.00 \\
\hline 4. & Seating capacity & $6(46.2 \%)$ & $4(30.8 \%)$ & $2(15.4 \%)$ & $1(7.7 \%)$ & 3.00 & 1.08 \\
\hline 5. & Shelf space & $7(53.8 \%)$ & $2(15.4 \%)$ & $3(23.1 \%)$ & $1(7.7 \%)$ & 3.23 & 1.01 \\
\hline 6. & Maintenance culture & $3(23.1 \%)$ & $3(23.1 \%)$ & $3(23.1 \%)$ & $4(30.8 \%)$ & 2.38 & 1.13 \\
\hline 7. & Technology & 7 (53.8\%) & - & $4(30.8 \%)$ & $2(15.4 \%)$ & 3.23 & 1.09 \\
\hline
\end{tabular}

Key: strengths (S), weaknesses $(\mathrm{W})$, opportunities $(\mathrm{O})$ or threats $(\mathrm{T})$ to infrastructure and facilities 
Table 5: Assessment of physical infrastructure and facilities by TASUED librarians

\begin{tabular}{|c|c|c|c|c|c|c|c|}
\hline $\mathbf{S} / \mathbf{N}$ & Statement & $\begin{array}{l}\text { SA (4) } \\
\text { Freq (\%) }\end{array}$ & $\begin{array}{c}A(3) \\
\text { Freq (\%) }\end{array}$ & $\begin{array}{c}D(2) \\
\text { Freq (\%) }\end{array}$ & $\begin{array}{l}\text { SD (1) } \\
\text { Freq (\%) }\end{array}$ & Mean & SD \\
\hline & Location and accessibility & & & & & & \\
\hline 1 & The library is centrally located for ease of access & $6(75 \%)$ & $2(25.0 \&)$ & - & - & 3.75 & 0.46 \\
\hline 2 & The library is in a comfortable and inviting location & $5(62.5 \%)$ & $3(37.5 \%)$ & - & - & 3.63 & 0.52 \\
\hline 3 & The library is accessible through good road network & $4(50 \%)$ & $4(50 \%)$ & - & - & 3.50 & 0.53 \\
\hline 4 & $\begin{array}{l}\text { Location is devoid of noise and other distractive } \\
\text { activities }\end{array}$ & $3(37.5 \%)$ & $3(37.5 \%)$ & $2(25 \%)$ & - & 3.13 & 0.83 \\
\hline 5 & Library environment offers sufficient aesthetic value & $2(25 \%)$ & $8(75 \%)$ & - & - & 3.25 & 0.46 \\
\hline 6 & $\begin{array}{l}\text { The library is well ventilated with suitable cooling } \\
\text { systems in place }\end{array}$ & $1(12.5 \%)$ & $3(37.5 \%)$ & $4(50 \%)$ & - & 2.63 & 0.74 \\
\hline 7 & There are adequate toilet facilities with water & - & $2(25 \%)$ & $4(50 \%)$ & $2(25 \%)$ & 2.00 & 0.76 \\
\hline 8 & The library is friendly to physically challenged & - & - & $3(37.5 \%)$ & $5(62.5 \%)$ & 1.38 & 0.52 \\
\hline 11 & $\begin{array}{l}\text { The library has enough and conducive space for } \\
\text { individual activities }\end{array}$ & $1(12.5 \%)$ & $4(50 \%)$ & $3(37.5 \%)$ & - & 2.75 & 0.71 \\
\hline 12 & The library can seat at least $20 \%$ of user population & - & $3(37.5 \%)$ & $4(50 \%)$ & $1(12.5 \%)$ & 2.25 & 0.71 \\
\hline 13 & $\begin{array}{l}\text { Each study space is between } 2.5 \text { and } 4 \text { square } \\
\text { meters }\end{array}$ & $1(12.5 \%)$ & $4(50 \%)$ & $3(37.5 \%)$ & - & 2.75 & 0.71 \\
\hline \multirow[t]{2}{*}{14} & $\begin{array}{l}\text { The electronic library can accommodate at least } 5 \% \\
\text { of the user population }\end{array}$ & $1(12.5 \%)$ & $1(12.5 \%)$ & $4(50 \%)$ & $2(25 \%)$ & 2.13 & 0.99 \\
\hline & Shelving space & & & & & & \\
\hline \multirow[t]{2}{*}{15} & Each stack area is at least 10.75 square meters & - & $4(50 \%)$ & $4(50 \%)$ & - & 2.50 & 0.53 \\
\hline & Light level & & & & & & \\
\hline
\end{tabular}

Key: Strongly Agreed = SA, Agreed = A, Disagreed = D, Strongly Disagree $=\mathrm{SD}$, Mean $=\bar{x}, \pm \mathrm{SD}=$ Standard deviation

Table 6: Perceived SWOT by TASUED librarians of physical infrastructure and facilities

\begin{tabular}{|c|c|c|c|c|c|c|c|}
\hline $\mathbf{S} / \mathbf{N}$ & Statement & $\begin{array}{c}S(4) \\
\text { Freq (\%) }\end{array}$ & $\begin{array}{c}\text { W (2) } \\
\text { Freq (\%) }\end{array}$ & $\begin{array}{c}O(3) \\
\text { Freq (\%) }\end{array}$ & $\begin{array}{c}\text { T (1) } \\
\text { Freq (\%) }\end{array}$ & Mean & SD \\
\hline 1. & Geographical Location of the library & $8(100 \%)$ & - & - & - & 4.00 & 0.00 \\
\hline 2. & Parking area & $2(25 \%)$ & $6(75 \%)$ & - & - & 2.50 & 0.93 \\
\hline 3. & Space for individual activities in the library & $3(37.5 \%)$ & $5(62.5 \%)$ & - & - & 2.75 & 1.04 \\
\hline 4. & Seating capacity & $5(62.5 \%)$ & $3(37.5 \%)$ & - & - & 3.25 & 1.04 \\
\hline 5. & Shelf space & $1(12.5 \%)$ & $6(75 \%)$ & - & $1(12.5 \%)$ & 2.13 & 0.83 \\
\hline 6. & Maintenance culture & - & - & - & $8(100 \%)$ & 1.00 & 0.00 \\
\hline 7. & Technology & . & - & 7 (87.5\%) & $1(12.5 \%)$ & 2.75 & 0.71 \\
\hline
\end{tabular}

Key: strengths $(\mathrm{S})$, weaknesses $(\mathrm{W})$, opportunities $(\mathrm{O})$ or threats $(\mathrm{T})$ to collections 
Table 7: Observation checklist on infrastructure and facilities of university libraries

\begin{tabular}{|c|c|c|c|c|c|c|c|c|c|c|}
\hline \multirow[b]{2}{*}{$\mathbf{S} / \mathbf{N}$} & \multirow[b]{2}{*}{ ITEM } & \multicolumn{3}{|c|}{ FUNAAB } & \multicolumn{3}{|c|}{ OOU } & \multicolumn{3}{|c|}{ TASUED } \\
\hline & & ME & NI & NO & ME & NI & NO & ME & NI & NO \\
\hline 1. & Location and Accessibility & & & & & & & & & \\
\hline 2. & The library is centrally located for ease of access & $\sqrt{ }$ & & & $\sqrt{ }$ & & & $\sqrt{ }$ & & \\
\hline 3. & The library is in a comfortable and inviting location & $\sqrt{ }$ & & & $\sqrt{ }$ & & & $\sqrt{ }$ & & \\
\hline 4. & The library is accessible through a good road network & $\sqrt{ }$ & & & $\sqrt{ }$ & & & $\sqrt{ }$ & & \\
\hline 5 & The location is devoid of noise and other distractive activities & $\sqrt{ }$ & & & & $\sqrt{ }$ & & & $\sqrt{ }$ & \\
\hline 6 & The library environment offers sufficient aesthetic value & \multicolumn{3}{|c|}{$\sqrt{ }$} & \multicolumn{3}{|c|}{$\sqrt{ }$} & $\sqrt{ }$ & & \\
\hline & Reader seating/space requirement & ME & NI & NO & ME & NI & NO & ME & NI & NO \\
\hline 7 & $\begin{array}{l}\text { The library has enough and conducive space for individual } \\
\text { activities }\end{array}$ & & $\sqrt{ }$ & & & $\sqrt{ }$ & & & $\sqrt{ }$ & \\
\hline 8 & $\begin{array}{l}\text { The library is well ventilated with suitable cooling systems in } \\
\text { place }\end{array}$ & & $\sqrt{ }$ & & $\sqrt{ }$ & & & & $\sqrt{ }$ & \\
\hline 9 & $\begin{array}{l}\text { The electronic library can accommodate at least } 5 \% \text { of the user } \\
\text { population }\end{array}$ & & $\sqrt{ }$ & & & $\sqrt{ }$ & & & $\sqrt{ }$ & \\
\hline 10 & There are adequate toilet facilities with water & & $\sqrt{ }$ & & $\sqrt{ }$ & & & & $\sqrt{ }$ & \\
\hline \multirow[t]{2}{*}{11} & The floor is noise free & $\sqrt{ }$ & & & & $\sqrt{ }$ & & & $\sqrt{ }$ & \\
\hline & Shelving space & ME & NI & NO & ME & NI & NO & ME & NI & NO \\
\hline \multirow[t]{2}{*}{12} & Each stack area is spacious & $\sqrt{ }$ & & & $\sqrt{ }$ & & & $\sqrt{ }$ & & \\
\hline & Light level & ME & NI & NO & ME & NI & NO & ME & NI & NO \\
\hline 13 & The library is well illuminated & $\sqrt{ }$ & & & $\sqrt{ }$ & & & & $\sqrt{ }$ & \\
\hline
\end{tabular}

Legend: Meets Expectation = ME, Needs Improvement $=$ NI, Not Observed $=$ NO

\section{Discussion}

The research question was formulated to establish the strengths, weaknesses, opportunities and threats of university libraries in Ogun State in terms of infrastructure and buildings. Findings are based on questionnaires responded to by professional librarians in the selected universities. A SWOT analysis of the university libraries is presented in Table 8. All the university libraries in this study are purpose-built buildings. They all satisfied the Librarians' Registration Council of Nigeria (LRCN) (Librarians' Registration Council of Nigeria [LRCN] 2019: 6) requirement of being centrally located and accessible through a good network of roads. They all have parking areas, however, from observation, the parking space at OOU needs improvement in terms of layout, and those of FUNAAB and TASUED need improvement in terms of size. The weakness of the limited parking area at the University of Malaya Library formed the basis for Hazidah and Edzan's (2012: 3) recommendation for the construction of a multi-level parking space. Results on the strengths of the geographical locations observed in this study agree with the findings of Kumar (2012) for the four university libraries in Kerala, India, and of Hazidah and Edzan (2012: 3) for the University of Malaya Library. A weakness of all the libraries in this study is the lack of friendliness to the physically challenged. All the libraries are multi-storey buildings with no elevators which is similar to a weakness observed in the SWOT analysis of Kerala University Library by Kumar (2012: 8). A LRCN standard (LRCN 2019: 6) requires that libraries be accommodating to the physically challenged. Another weakness in this study is that the libraries in the study are noisy. OOU Library is located close to a hall that hosts events. TASUED Library has a large lecture theatre directly opposite it. Locations devoid of noise and other distractive activities is also an LRCN standard requirement (LRCN 2019: 6). In accordance with LRCN (2019) standards, all libraries in this study have strengths in terms of shelving, space for individual activities, ventilation, and lighting.

All libraries in this study have weaknesses of not being able to seat $20 \%$ of their user populations and electronic libraries that are not able to accommodate $5 \%$ of the user population. User populations are $14,608,25,000$, and 4,110 for FUNAAB, OOU and TASUED respectively. The seating capacities of the libraries are 824 (FUNAAB), 800 (OOU) and 753 (TASUED). The e-library capacities are fifty, seventy and 165 for FUNAAB, OOU and TASUED respectively. LRCN (2019: 6) and the Association of University Librarians of Nigerian Universities (Balarabe et al. 2016: 77) standards require sufficient space for at least $20 \%$ of the user population. Adequate space for an ICT laboratory that can accommodate at least $5 \%$ of the user population is also a LRCN standard requirement (LRCN 2019: 14). Librarians in the universities in the study rated seating capacity as strengths of their university libraries. This rating is likely to have been based on patronage which perhaps did not put any pressure on seating capacity. A study by Nkamnebe, Udem and Nkamnebe (2014:1) on the extent of library 
use revealed that students fairly regularly used the library for their studies but used the library most during the examination period. The latter position concurs with the opinion of most university librarians in this study.

Technology is regarded as an opportunity in terms of the SWOT analysis of the infrastructure and buildings of the university libraries studied. Closed-circuit television is available in the federal university and one state university. Tertiary Education Trust Fund (TETFund) intervention is an opportunity for library infrastructure and buildings. The university library at OOU is a TETFund project. FUNAAB has enjoyed TETFund intervention for repairs and TASUED for library furniture (Osinulu and Daramola 2017: 44). Maintenance of infrastructure and facilities was rated as a threat to infrastructure and buildings. Maintenance of infrastructure was likewise reported as a threat in the SWOT analysis of the UBC Library by De Bruijn (2000: 3). Funding and the economic situation of the country are also recurring threats in this respect.

Table 8: SWOTs quadrant for infrastructure and facilities of government owned university libraries in Ogun State, Nigeria

\begin{tabular}{|c|c|}
\hline $\begin{array}{l}\text { STRENGTHS } \\
\text { - } \quad \text { Libraries are centrally located for easy access } \\
\text { - } \quad \text { Libraries are in comfortable and inviting locations accessible } \\
\text { through good road networks } \\
\text { - } \quad \text { Parking area } \\
\text { - } \quad \text { Libraries are well ventilated and well illuminated } \\
\text { - } \quad \text { There is adequate and conducive space for individual activities } \\
\text { - }\end{array}$ & $\begin{array}{l}\text { WEAKNESSES } \\
\text { - } \quad \text { Library buildings and facilities are not friendly to the physically } \\
\text { challenged (all libraries are multi-storey buildings without } \\
\text { elevators) } \\
\text { - Location not devoid of noise in the two state-owned university } \\
\text { libraries } \\
\text { - } \quad \text { The libraries cannot seat } 20 \% \text { of the user population } \\
\text { - } \quad \text { phe electronic libraries cannot accommodate } 5 \% \text { of the user } \\
\text { - Floors are not noise-free in the two state-owned university } \\
\text { - } \quad \text { Aderaries } \\
\text { owned university libraries) } \\
\text { Space for individual activities, shelves, toilet facilities with } \\
\text { water, and parking area (TASUED) }\end{array}$ \\
\hline
\end{tabular}

\section{Conclusion and recommendation}

Uppermost among the strengths of infrastructure are geographical location and accessibility through a good road network. Libraries not being accommodating to the physically challenged is the biggest weakness, while technology is the major strength of infrastructure and buildings. Poor maintenance of infrastructure and facilities as well as funding are threats. Technology is an opportunity. TETFund intervention offers an opportunity for infrastructural development and improvement. Efforts should be made to address the issue of the accessibility of the libraries to the physically challenged as observed in the construction of the libraries studied. Future library buildings should have an endorsement from LRCN before construction. The libraries in the study can consider expanding their facilities to seat more users on the assessment of patronage. LRCN and NUC should consider reviewing requirements on seating capacity considering the opportunity offered by technology that allows users to access the library from anywhere.

\section{References}

Amusa, O.I., Iyoro, A.O. and Olabisi, A.F. 2013. Work environments and job performance of librarians in the public universities in South-west Nigeria. International Journal of Library and Information Science. 5(11): 457-461. DOI:10.5897/IJLIS2013.0404.

Arthur, C., Brafi, P.O. and Kuranchie, A. 2013. The use of academic libraries among students in tertiary institutions in the Sunyani Municipality, Ghana. Journal of Education and Practice, 4(2): 117-126.

Asiabaka, I.P. 2008. The need for effective facility management in schools in Nigeria. New York Science Journal, 1(2): $10-21$.

Balarabe, A.A., Anunobi, C., Nkiko, C. and Idiodi, E.O., Eds. 2016. A compendium of Association of University Librarians of Nigerian Universities (AULNU) and Nigerian university libraries. Zaria: Ahmadu Bello University Press.

De Bruijn, E. 2000. UBC library SWOT analysis. [Online]. https://www.scribd.com/document/409090579/UBCLibraryswotanalysis-pdf.

Ghosh, M. 2006. The emerging role of the national and regional association in library development: an India perspective. Library Review, 55(1): 45-56. 
Hazidah, N.A. and Edzan, N.N. 2012. The SWOT analysis: marketing and promotional strategies used at the University of Malaya Library. Paper presented at the International Conference on GenNEXT Libraries. 8-10 October. Universiti Brunei Darussalam. [Online]. http://eprints.um.edu.my/5031/ (23 July 2014).

Iwhiwhu, B.E., and Okorodudu, P.O. 2012. Public library information resources, facilities and services: user satisfaction with Edo State central Library, Benin City, Nigeria. Library Philosophy and Practice (e-journal), 747. [Online]. http://digitalcommons.unl.edu/libphilprac/747/.

Kumar, S.P.K. 2012. University libraries in Kerala: SWOT analysis for marketing. Library Philosophy and Practice (ejournal), 787. [Online]. http://digitalcommons.unl.edu/libphilprac787.

Librarians' Registration Council of Nigeria (LRCN). 2019. Standards and guidelines for academic libraries in Nigeria. Abuja: LRCN

Nkamnebe, E.C.,Udem, O.K. and Nkamnebe, C.B. 2014. Evaluation of the use of university library resources and services by the students of Paul University, Awka, Anambra State, Nigeria. Philosophy and Practice (e-journal), 1147. [Online]. http://digitalcommons.unl.edu/libphilprac/1147/.

Ogbuiyi, S.U. and Okpe, I.J. 2013. Evaluation of library materials usage and services in private universities in Nigeria. Arabian Journal of Business and Management Review (Kuwait Chapter), 2(8): 33-41.

Ogunsola, I.O. and Ikegune, D. O. 2016. Management and preservation of non-book materials in academic libraries: a case study of three university libraries in Nigeria. Library Philosophy and Practice (e-journal), 1371. [Online]. http://digitalcommons.unl.edu/libphilprac/1371/.

Okoro, C.C., Omeluzor, S.U. and Bamidele, I.A. 2014. Effect of brain drain (human capital flight) of librarians on service delivery in some selected Nigerian universities. SAGE Open, 1(11) DOI:10.1177/2158244014541131.

Omeluzor, S.U., Nwosu, C.C and Molokwu, U.E. 2018. Effects of library infrastructure on turnover intentions of librarians: a study of university libraries in South-South and South-East of Nigeria. Library Philosophy and Practice (e-journal), 1967. [Online]. http://digitalcommons.unl.edu/libphilprac/1967/.

Osinulu. L.F. and Daramola, C.F. 2017. Government intervention in the funding of Nigerian university libraries: an appraisal of the role of the Tertiary Education Trust Fund (Tetfund). Agogo: Journal of Humanities, 3: $41-47$.

Oyedum, U.G. 2011.Physical facilities as determinants of undergraduate students' use of federal university libraries in Nigeria. Library Philosophy and Practice (e-journal), 616. [Online]. http://digitalcommons.unl.edu/libphilprac/616/.

Panagiotou, G.D. 2003. Bringing SWOT into focus. Business Strategy Review, 14(2): 8-10.

Shill, H.B. and Tonner, S.T. 2003. Does the building really matter? Facility improvements and library usage. Paper presented at the 11 ${ }^{\text {th }}$ National ACRL Conference. 10-13 April. Charlotte, North Carolina. [Online]. http://www.ala.org/acrl/sites/ala.org.acrl/files/content/conferences/pdf/shill.PDF.

Ugah, A.D. 2007. A SWOT analysis of the university library of Michael Okpara University of Agriculture Library, Umudike, Nigeria. Library Philosophy and Practice (e-journal), 148. [Online]. http://digitalcommons.unl.edu/libphilprac/148/. 